\title{
Evaluation of SWAT Performance on a Mountainous Watershed in Tropical Africa
}

\author{
Isaac Mutenyo ${ }^{1}$, A Pouyan Nejadhashemi ${ }^{2 *}$, Sean A Woznicki ${ }^{2}$ and Subhasis Giri²
}

${ }^{1}$ Kyambogo University, Department of Civil and Building Engineering, Uganda

${ }^{2}$ Michigan State University, Department of Biosystems and Agricultural Engineering, USA

\begin{abstract}
Soil and water assessment Tool is used to model the hydrology of a mountainous catchment in tropical Africa. Land cover and soil characteristics for the catchment were used to determine initial model parameters that were later adjusted during a calibration process. The model was calibrated and validated against measured stream flow. Although the model performed satisfactorily for simulating monthly river flows based on SWAT model calibration guidelines, it fell short of capturing daily peak flows. Average error on prediction of daily peak flows was $-19.8 \%$, while the median error was $10.8 \%$. Overall, the average simulated daily peak flow was $2.6 \mathrm{cms}$ less than the corresponding observed daily peak flow, indicating a model tendency to under predict the magnitude of peak events. The inability of the model to capture peak flows was found to be the main limiting factor for its performance.
\end{abstract}

Keywords: Manafwa; Uganda; Watershed; SWAT; Hydrologic modeling; Mountainous regions

\section{Introduction}

Information on natural condition and form of water resources occurrence is essential for socio economic development. Such information is obtained by carrying out a water resources assessment, a process that involves developing a clear understanding of water inflows, storage and outflows and their interrelationship over time. Only then is it possible to estimate environmental flow that is required to sustain human and natural resources uses. Meanwhile, water resources management in developing countries is more profound and complex than developed countries. In developing countries the lack of reliable long-term data makes rigorous and accurate water resources assessments challenging. Although water resources information acquisition requires considerable resources, its value far outweighs the costs of data collection. For example benefit to cost ratios for hydrologic data collection of up to 40:1 has been reported [1]. These benefits point to the need for adopting alternative methods that enable water resource assessments to be undertaken for developing countries.

The key steps in carrying out a water resources assessment development process are highlighted in WMO [1]. A fundamental step in this process is the long term simulation of watershed behavior. This can be achieved by using conceptual hydrologic models that represent the physical processes in the watershed. The choice of model depends on the nature of the watershed and the amount and reliability of hydrologic data available. What features of the actual system are incorporated into a model depends partly on what the modeler judges to be important with respect to the task at hand. How well this is done will depend on the skill of the modeller, time, and the money available and perhaps more importantly the modeller's understanding of the system dynamics [2]. The choice of approach therefore depends primarily on the issues that the researcher is investigating and also importantly the availability and accuracy of the data used. The effectiveness of a model in simulating the behavior of the catchment depends largely on the model parameters [3] and on how well the model structure is defined and how the model parameters are determined [4-5].

Developments in computer technology and recent advances in the use of geographic information systems (GIS) for water resources management have revolutionized the study of hydrologic systems.
Since the 1990s there has been concerted effort to integrate hydrologic models and GIS with the aim of analyzing spatial and temporal datasets. The Soil and Water Assessment Tool (SWAT) developed by the United States Department of Agriculture- Agricultural Research Services (USDA-ARS) is one such model that integrates the spatial analysis advantages of GIS with the temporal analysis advantages of hydrologic modeling [6]. SWAT is a conceptual continuous time hydrologic model that can help water resource managers in assessing water supplies and non-point source (NPS) pollution on watersheds and large river basins [7]. It uses the basic principles of the hydrologic cycle to simulate the behavior of a watershed. Because the model can be run as an interface on GIS it facilitates the aggregation of required input data for simulating large scale watersheds. SWAT considers a watershed divided into sub basins based on topography, soil and land use and thus preserves the spatially distributed parameters of the entire watershed and homogenous characteristics within a basin [7].

Since its development in the 1990s, the SWAT model has been widely applied and improved to suit different watershed conditions. The model has proved to be an effective tool for assessing water resources and NPS pollution problems for a wide range of scales and environmental conditions across the globe [7]. A review of advances in the use of the SWAT model has been performed by Krishnan et al. [8] while Gassman et al. [7] outlines the history and developments of the model. For example, a national scale model, the Hydrologic Unit Model for the United States (HUMUS) used SWAT to analyze the effect of management scenarios on the water quality and quantity. It is being used to perform Total Maximum Daily Load (TMDL) analyses, which must be performed for impaired waters by different states as

*Corresponding author: A Pouyan Nejadhashemi, Department of Biosystems and Agricultural Engineering, Michigan State University, USA, Tel: (517) 432-7653; Fax: (517) 432-2892; E-mail: pouyan@msu.edu

Received April 30, 2013; Accepted September 02, 2013; Published September 07,2013

Citation: Mutenyo I, Nejadhashemi AP, Woznicki SA, Giri S (2013) Evaluation of SWAT Performance on a Mountainous Watershed in Tropical Africa. Hydrol Current Res S14: 001. doi:10.4172/2157-7587.S14-001

Copyright: ( 2013 Mutenyo I, et al. This is an open-access article distributed under the terms of the Creative Commons Attribution License, which permits unrestricted use, distribution, and reproduction in any medium, provided the original author and source are credited. 
mandated by the 1972 U.S. Clean Water Act [9]. It has been used to perform macro-scale assessments on watersheds such as the Upper Mississippi river basin. Regarding climate change, SWAT has been used together with other models to quantify the impacts of climate change for different watersheds within the Climate Hydrochemistry and Economics of Surface-water systems (CHESS) project [7].

One fundamental advantage of SWAT is its ability to model ungauged or poorly gauged watersheds [10]. This makes it attractive for use in developing countries where there is inadequate infrastructure to measure required inputs for hydrologic modeling.

Many studies have been performed regarding the application of SWAT in Africa. Abaho et al. [11] used an uncalibrated SWAT model to evaluate the impacts of climate change on flow discharge and groundwater recharge in the Sezibwa catchment in Uganda. A $47 \%$ increase in average flow rate and up to a $40 \%$ increase in recharge was observed for the period of 2070-2100. However, there are high levels of uncertainty associated with the model predictions and climate change scenarios that should be evaluated in future studies. Another uncalibrated SWAT model evaluation was performed by Mulungu and Munishi [12]. They reported the model's inability to adequately estimate peak flows. However, since the model was not calibrated, the results are not reliable.

Ndomba et al. [13] determined SWAT applicability to a wetland catchment in Rwanda based on daily flow calibration. However, the results showed poor model performance in capturing high flow rates (greater than $3 \mathrm{cms}$ ) and peak flows during the calibration period, while significantly under-predicting at the end of the validation period. Nyeko [14] used SWAT to evaluate the impact of landuse change on water resources in a large watershed $\left(12,225 \mathrm{~km}^{2}\right)$ in Uganda. The model was calibrated on a monthly basis; however, the results showed the SWAT model is incapable of capturing peak flows on a daily basis. Another large scale SWAT study by Melesse et al. [15] showed the significant flow reduction (46\%) can be expected if rainfall volume is reduced by $20 \%$. However, daily flow prediction was not compared. Similarly, successful SWAT applications in tropical watersheds were reported [16-18]. However, model performance on daily time-step was not evaluated.

The SWAT model was used in Africa to model the hydrology of the Sondu river basin (area of $3050 \mathrm{~km}^{2}$ ) located in Western Kenya [8]. The calibrated model had a Nash-Sutcliffe Efficiency (NSE) of only 0.10 and because it was the first step in the application of SWAT to African basins itsresults were considered as only preliminary [8]. Other applications of SWAT to different catchments in East Africa have been attempted with varying levels of success. Ndomba et al. [19] validated the application of the SWAT model in the Pangani river basin in north eastern Tanzania. Their study resulted in a calibrated model with a NSE of 0.54 for daily and 0.65 for monthly flows which was considered satisfactory. This study suggested that the SWAT model could be used in un-gauged, data scarce catchments for identifying hydrological controlling factors/parameters. Birhanu [20] used SWAT to model the Kihansi river basin (area of $581 \mathrm{~km}^{2}$ ) in south central Tanzania where it was observed that prediction efficiency of the model could be improved by increasing the spatial and temporal scale of the data used. In Uganda, Kingston and Taylor [21] used SWAT to model the river Mitano basin in the South western part of the country. The resultant NSE for the calibrated model was -0.09 for a monthly time step indicating that the model was slightly less useful than the observed long term monthly mean discharge [13]. A critical review of the application of SWAT in the upper Nile basin countries was done by Van Griensven et al. [22]. In this review, on the basis of performance indicators, the majority of SWAT models were classified as giving satisfactory to very good results. However, it was noted that in several cases unrealistic parameter values were reported. A critical finding of this review was that a comparison of SWAT application on the same or similar case studies but by different research teams and/or model versions resulted in very different results. These findings call for further studies and assessments on the application of the SWAT model to watersheds especially in the tropical regions of Africa.

Given the limited SWAT model application and the varying levels of its success in Africa there is a need for continued review and improvement of the use of the model to assess its performance especially in mountainous areas of tropical Africa. Most previous studies have used SWAT to model non-mountainous catchments or mountainous catchments at very large sizes. As no two watersheds are alike in their physiographic and climatologically, the results of these studies cannot be extended to other locations because hydrologic responses differ under the same drivers (rainfall, temperature, etc.).The present study focuses on the application of SWAT to a relatively small size, mountainous watershed and specifically assesses its effectiveness as a modelling tool in tropical watersheds. In this study the SWAT model is used to model the hydrology of the Manafwa river basin in eastern Uganda. Specifically the study focuses on assessing the effectiveness of the model in predicting the flows of river Manafwa.

\section{Materials and Methods}

\section{The study area}

The Manafwariver basinis located in eastern Uganda and comprises an area drained by the ManafwaRiver.River Manafwa has its source on the high points of Mt. Elgon at an elevation of 2,161 m. The River flows through the mountainous districts of Bududa, Manafwa andMbale and the low lying Butaleja where it joins with other streams to form the greater river Mpologoma that flows into Lake Kyoga.This river is part of the greater river Nile basin. The watershed studied includes the drainage areaof the river upstream of stream gauge No. 82212 located at Busiu, $34.16^{\circ} \mathrm{E}$ and $0.94^{\circ} \mathrm{N}$ (Figure 1).

The river has great socioeconomic importance to the population that lives within the watershed. The main socioeconomic activities in the basin are agriculture, agro-forestry, sand mining and stone quarrying. Farming is by far the primary activity. Main crops grown include bananas (matooke), Arabica coffee, maize, beans, onions and cabbages in the highland areas of Bududa and Manafwa and rice, maize, cotton and millet in the low lands of Mbale and Butaleja. Agriculture is mainly rain-fed with minimal irrigation practiced only at a small scale level in the low lying areas to the west. The area receives average annual rainfall of $1500 \mathrm{~mm}$ in a bimodal pattern separated by dry seasons during December to February and July. Temperature ranges from $14^{\circ}$ to $33^{\circ} \mathrm{C}$ with an average of $23^{\circ} \mathrm{C}$. Soil types are those conditioned by topography and tropical climate, namely Nitisols, Cambisols, Lixisols, Ferralsols, Leptosols, Gleysols, and Acrisols [23]. The infiltration rate is generally rapid in the top soils, allowing fast flow of water into the deeper horizons. Soil erosion is a major land degradation process and it is estimated that $75-80 \%$ of Bududa district is severely affected by soil erosion [24]. River Manafwa is characterized by high levels of sediments, pollution from uncontrolled waste disposal and frequent flooding and drought as seen from physical observation of the river. There are minimal field measurements for physical-chemical parameters and none for sediments on the river course. The lack of 


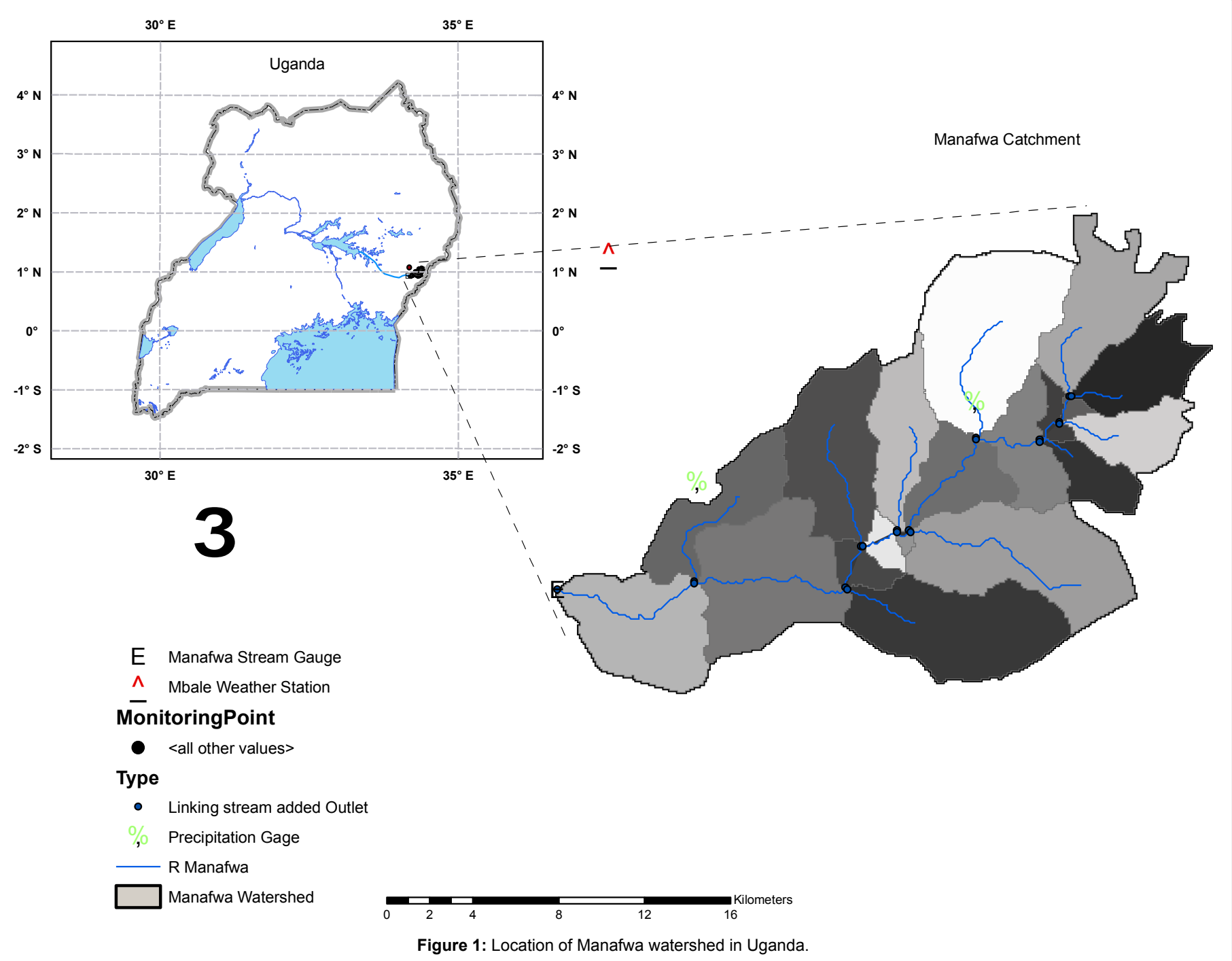

hydrologic data and information complicates any effort to guide policy for addressing the prevailing challenges.

River Manafwa is a source for domestic water supply to the surrounding built up areas. In addition there are several groundwater boreholes installed with hand pumps supplying water to rural communities across the watershed. The river is the sole source of irrigation water to the Doho rice scheme which is located in the river flood plain in the low lying areas in the neighbouringButaleja district to the west of the watershed.Doho rice scheme together with the surrounding small holder rice schemes represents the largest rice production in Uganda, covering an area of over $20 \mathrm{~km}^{2}$.

\section{Model set up}

The SWAT model is based on the principle that a water balance is the driving force behind everything that happens in a watershed. The model simulates the occurrence of the hydrologic cycle in a watershed. A detailed description of the different physical processes and the formulations of these processes and how they relate with each other in a watershed are presented in Neitsch et al. [25]. The hydrologic cycle as simulated by SWAT is described by the water balance equation [25].

$$
S W_{t}=S W_{o}+\sum_{i=1}^{t}\left(R_{\text {day }}-Q_{\text {surf }}-E_{a}-w_{\text {seep }}-Q_{g w}\right)
$$

where $S W_{t}$ is the final soil water content $\left(\mathrm{mm} \mathrm{H}_{2} \mathrm{O}\right), S W_{o}$ is the initial soil water content on day $i\left(\mathrm{~mm} \mathrm{H}_{2} \mathrm{O}\right), t$ is the time (days), $R_{d a y}$ is the amount of precipitation on day $i\left(\mathrm{~mm} \mathrm{H}_{2} \mathrm{O}\right), Q_{\text {surf }}$ is the amount of surface runoff on day $i\left(\mathrm{~mm} \mathrm{H}_{2} \mathrm{O}\right), E_{a}$ is the amount of evapotranspiration on day $i(\mathrm{~mm} \mathrm{H} 2 \mathrm{O}), w_{\text {seep }}$ is the amount of water entering the vadose zone from the soil profile on day $i\left(\mathrm{~mm} \mathrm{H}_{2} \mathrm{O}\right)$ and $Q_{g w}$ is the amount of return flow on day $i\left(\mathrm{~mm} \mathrm{H}_{2} \mathrm{O}\right)$.Each of the physical processes occurring in the watershed are simulated using spatial and temporal input data that is first classified and prepared into model-compatible formats. For un-gauged watersheds without measured weather input data and for missing data in partially gauged watersheds, SWAT has an inbuilt weather generator to simulate missing weather information.

For this study the model was run as an extension (ArcSWAT) on ArcGIS 9.3. This extension requires the designation of land use, soil, weather, groundwater, water use, management, soil chemistry, pond and stream water quality data as well as the simulation period in order to ensure a successful simulation [26].

The first step in the model setup was to delineate the watershed 
that consists of the area drained by the river and then dividing the watershed into sub-basins that drain into the river tributaries. The sub-basins were delineated by an automatic procedure using Digital Elevation Model (DEM) data of eastern Uganda. The sub basins were then further subdivided into hydrologic response units (HRU) that represent homogenous land use, slope, and soil type. In total 19 sub basins and 108 HRUs were generated by this process. The HRUs were generated using a threshold value of $30 \%$ for land use, soil, and slope. This implied that an area could qualify to be an HRU only if the land use, soil type or slope category is more than $30 \%$ of the total sub basin area.

\section{Data sources and description}

Input data to the model included a DEM of east Uganda, land use and land cover for Uganda, Soil classification and weather data. Much of the existing data did not adhere to the formats compatible with the SWAT model. This necessitated prior rigorous data preparation and classification which was aimed at converting input data to formats compatible with SWAT datasets.

Digital Elevation Model (DEM): A DEM for eastern Uganda was obtained from the United States Geological Surveys (USGS) website (http://gdex.cr.usgs.gov/gdex/). The DEM product was the Shuttle Radar Topography Mission (STRM $90 \mathrm{~m}$ ) with a $90 \mathrm{~m}$ resolution. This DEM was used as input for automatic watershed delineation and stream generation.

Land Use/Land Cover Data: Land use and land cover data for Uganda were obtained from the Africover datasets of the Food and Agriculture Organization (FAO) of the United Nations [27] available at http://www.fao.org/geonetwork/srv/en/metadata. show? $i d=38103 \&$ currTab=simple. Data was interpreted from the LANDSAT imagery (bands $4,3,2$ ) acquired in the year 2001. It is available as a public domain spatially aggregated dataset and was downloaded as an ESRI Arc View shape file at a scale of 1:100,000. The description and classification of the land use and land cover was based on the FAO Land Cover Classification System's (LCCS) standard description. The land cover class descriptions were used to generate the SWAT land cover code to be modelled for each category in the land use map grid.

Soil Data: Soil data was obtained from the FAO-UNESCO harmonized world soil database (HWSD) version 3.6,2003 [28] available at:http://www.fao. org/geonetwork/srv/en/metadata. show? id=14116\&currTab=distribution/. This soil dataset identifies two soil groupings in the delineated Manafwa watershed: $\mathrm{Nh} 2-2 \mathrm{c}$ with Humic Nitosols as a dominant soil unit found in the high altitude areas and Fo47-2ab with Orthic Ferrasolsas a dominant soil unit found in the low lying areas. Soil properties required as input to the SWAT model were generated from soil characteristics of these two soil units available in the FAO dataset and other soil information obtained from other sources more specific to Eastern Uganda [23,24,28,29,30,31, and 32].

Weather Data: Daily rainfall data from three rain gauge stationsBududa (ID No. 8834027), Mbale(ID No. 8834002) and Nabumali (ID No. 8934053) wereavailable for use. Records available were for different periods spanning from 1943 to 1980 . Only the Bududa rain gauge is located within the watershed. Rainfall data were checked for consistency and compared with available stream flow data. Consistent data for rainfall and stream flow were found to be for the period 1955 to 1961. The Mbale weather station had the longest rainfall data record and it also had monthly data for temperature, dew point, wind speed and relative humidity that are required inputs for the SWAT weather generator. Monthly solar radiation records were not available and therefore solar radiation was estimated from monthly global solar irradiation maps of Uganda developed by Mubiru and Banda [33]. Rain gauge data was obtained from the Uganda Ministry of Water and Environment (MWE), Directorate of Water Resources. Additional weather data for Mbale used as input to the weather generator was obtained from the US National Oceanic and Atmospheric Administration (NOAA) archives available at http://gis.ncdc.noaa.gov/map/viewer/\#app=cdo.

Stream flow Data: There is only one stream gauge in the watershed, the Manafwa river gauge (station ID 82212) located at the outlet of the delineated watershed at $34.16^{\circ} \mathrm{E}$ and $0.94^{\circ} \mathrm{N}$. Daily stream flow records are available at this station for the period 1949 to 2011 but with some missing data during the period. Observed stream flow data for the period 1955 to 1961 was used for model calibration and validation because this period had available rainfall data from the three rain gauge stations used as precipitation input to the model.

\section{Model calibration and validation}

The first step in the calibration and validation process in SWAT is the determination of the most sensitive parameters for a given watershed [34]. This can be achieved by a sensitivity analysis. Sensitivity analysis is aimed at determining the rate of change of model outputs caused by a change of model input parameters. It is a necessary process to identify key parameters and parameter precision required for calibration [35]. An essential output of a sensitivity analysis is a ranking of model parameters according to how sensitive model outputs are to changes in the model input parameters. This ranking can guide model calibration because it will inform the modeller on which parameters to adjust during calibration. A sensitivity analysis was performed with and without observed data of the Manafwa river flow at the catchment outlet.

Model calibration is the process of estimating model parameters by comparing model predictions for a given set of assumed conditions with observed data for the same conditions [35]. Manafwa river flow data for 1955-1959 was use for calibration. This period was selected because it had the longest record without gaps (only 3.7\% missing data) and rainfall data for this period was available for the three rain gauges. Calibration was performed in two steps. First auto-calibration was performed with the 19 most sensitive parameters as input using the parameter solution (Parasol) method. Model parameters were further improved by manual calibration using an approach suggested by Arnold et al. [36] and a generalized flow chart presented by Arnold et al. [34]. Model efficiency was evaluated by the Nash-Sutcliffe Efficiency (NSE) [37], the Percent Bias (PBIAS), and the Root Mean Square observations Standard Deviation Ratio (RSR). Model calibration was aimed at achieving a satisfactory model efficiency of concurrently having NSE $\geq 0.5$, PBIAS of \pm 25 , and RSR of $<0.7$ for a monthly time step as recommended by Moriasi et al. [35].

Model validation is the process of demonstrating that a given site specific model is capable of making sufficiently accurate simulation, although "sufficiently accurate" can vary based on project goals [38]. It involves running the calibrated model to predict outputs for a given period and then comparing the predicted results with observed data for the same period. In essence this means that observed data is divided into two parts, in which one part is used for calibration and the other for validation. Manafwa river flow data for the period 19601961 collected at the outlet of the watershed was used for validation. Although stream flow data beyond 1961 was available, there was no corresponding rainfall data beyond this period. The model was only calibrated for stream flow due to lack of observed data for sediment and nutrients. 


\section{Results and Discussion}

\section{Sensitivity analysis and parameter estimation}

The sensitivity analysis ranked parameters in the order of most sensitive. The first 19 ranked parameters were used for calibration (Table 1). The ranking of parameters with and without observed data is comparable as both rankings retained the same parameters as the 19 most important parameters. Significant differences in ranks occur in seven parameters; REVAPMN, SOL_Z, BLAI, GW_REVAP, CH_K2, CH_N2, and SURLAG. This compares well with results of Ndomba et al. [19] on a catchment in Pangani river basin in Tanzania.

Performing auto-calibration did not result in a reliable model. Therefore, manual calibration was conducted by adjusting only few parameters. The run off curve number (CN2) was adjusted by increasing it for all HRUs in intervals $10 \%$ from the initial value. The surface runoff lag coefficient (SURLAG) was reduced for the entire basin to 0.01 . Soil parameters; soil available moisture (SOL_AWC), soil depth (SOL_Z) and saturated conductivity (SOL_K) were adjusted in multiples of $5 \%$. The HRU average slope steepness was also adjusted by progressively reducing it by $10 \%$. Adjusting these parameters caused significant improvement to model efficiency. Although groundwater parameters; threshold depth of water on the shallow aquifer required for return flow to occur (GWQMN), threshold depth of water in the shallow aquifer for returning to the root zone due to moisture deficit or percolation to the deep aquifer (REVAPMN) were ranked high in the sensitivity analysis, changing them did not improve the model efficiency and therefore they remained at the initial values. Meanwhile, the available water capacity of soil, which ultimately controls the surface runoff storage of the basin was identified as a primary contributor to stream flow while the contribution from groundwater flow is less significant. In addition, the soil depth in the watershed has been reported to be as high as four meters in some areas [32]. The large volume of water held in the soil is a likely contribution to the stream flow during the periods when there is no surface runoff.

\section{Model calibration and validation procedure}

For the calibration period the model efficiency (NSE) was 0.72 , while the PBIAS was $-0.49 \%$ and RSR was 0.53 for a monthly time interval. The monthly values for NSE, PBIAS and RSR for the validation period were $0.64,20.5 \%$ and 0.60 respectively. Therefore, according to model evaluation a criterion introduced by Moriasi et al. [35] model calibration is satisfactory. Monthly average observed and simulated flows for the period 1956-1961 are presented in Figure 2.

Model efficiency for simulation at a daily time step is reduced in comparison to model performance on monthly basis. For the daily time step, the values for NSE, PBIAS and RSR are $0.50,2.32 \%$ and 0.71 respectively for the calibration period. This reduced efficiency may be attributed to inadequate rain gage data in the study area. Figure 3 shows daily observed and simulated flows for the calibration period 1956 - 1959 while Figure 4 shows the validation period (1960-1961). For the validation period, NSE is 0.46 for a daily time step. The daily model simulation (Figure 3 and 4) revealed that the calibrated model's performance is limited in capturing the peak stream flow, under predicting peak flow events by an average of $2.6 \mathrm{cms}$. Overall average and median peak flow error were $-19.8 \%$ and $10.8 \%$, respectively. This is particularly true for the wet months of May to August when the observed flows are twice as much as the corresponding simulated flows in some years. The fact that poor model performance coincides with periods of high precipitation could mean that the likely cause of this is associated with precipitation. A similar result of failure of the model to

\begin{tabular}{|c|c|c|c|}
\hline \multirow[b]{2}{*}{ Parameter } & \multirow[b]{2}{*}{ Description } & \multicolumn{2}{|c|}{ Rank } \\
\hline & & $\begin{array}{c}\text { Without } \\
\text { Observed Data }\end{array}$ & $\begin{array}{l}\text { With observed } \\
\text { Data }\end{array}$ \\
\hline $\mathrm{CN} 2$ & $\begin{array}{l}\text { SCS Curve number for } \\
\text { moisture condition II }\end{array}$ & 1 & 1 \\
\hline CANMX & Maximum canopy index & 2 & 2 \\
\hline ESCO & $\begin{array}{c}\text { Soil evaporation compensation } \\
\text { factor }\end{array}$ & 3 & 3 \\
\hline GWQMN & $\begin{array}{l}\text { Threshold depth of water in } \\
\text { the shallow aquifer required for } \\
\text { return flow to occur }\left(\mathrm{mm} \mathrm{H}_{2} \mathrm{O}\right)\end{array}$ & 4 & 4 \\
\hline SOL_AWC & $\begin{array}{c}\text { Available water capacity of the } \\
\text { soil layer }(\mathrm{mm})\end{array}$ & 5 & 7 \\
\hline REVAPMN & $\begin{array}{l}\text { Threshold depth of water in the } \\
\text { shallow aquifer for "revap" or } \\
\text { percolation to the deep aquifer } \\
\text { to occur }\left(\mathrm{mm} \mathrm{H}_{2} \mathrm{O}\right)\end{array}$ & 6 & 13 \\
\hline SOL_Z & Soil depth $(\mathrm{mm})$ & 7 & 11 \\
\hline BLAI & $\begin{array}{l}\text { Maximum potential leaf area } \\
\text { index }\end{array}$ & 8 & 12 \\
\hline GW_REVAP & $\begin{array}{c}\text { Ground water "revap" } \\
\text { coefficient }\end{array}$ & 9 & 14 \\
\hline ALPHA_BF & Baseflow alpha factor (days) & 10 & 8 \\
\hline $\mathrm{CH} \_\mathrm{K} 2$ & $\begin{array}{l}\text { Effective hydraulic conductivity } \\
\text { in the main channel alluvium } \\
(\mathrm{mm} / \mathrm{hr})\end{array}$ & 11 & 5 \\
\hline SOL_K & $\begin{array}{l}\text { Saturated hydraulic conductivity } \\
\qquad(\mathrm{mm} / \mathrm{hr})\end{array}$ & 12 & 9 \\
\hline SLOPE & $\begin{array}{l}\text { Average slope steepness } \\
(\mathrm{m} / \mathrm{m})\end{array}$ & 13 & 15 \\
\hline $\mathrm{CH} \_\mathrm{N} 2$ & $\begin{array}{c}\text { Manning's } \mathrm{n} \text { value for the main } \\
\text { channel }\end{array}$ & 14 & 6 \\
\hline GW_DELAY & Groundwater delay (days) & 15 & 16 \\
\hline SURLAG & Surface runoff lag coefficient & 16 & 10 \\
\hline EPCO & $\begin{array}{l}\text { Plant uptake compensation } \\
\text { factor }\end{array}$ & 17 & 17 \\
\hline SOL_ALB & Moist soil Albedo & 18 & 19 \\
\hline SLSUBBSN & Average slope length (m) & 19 & 18 \\
\hline
\end{tabular}

Table 1: Sensitivity analysis parameter ranking.

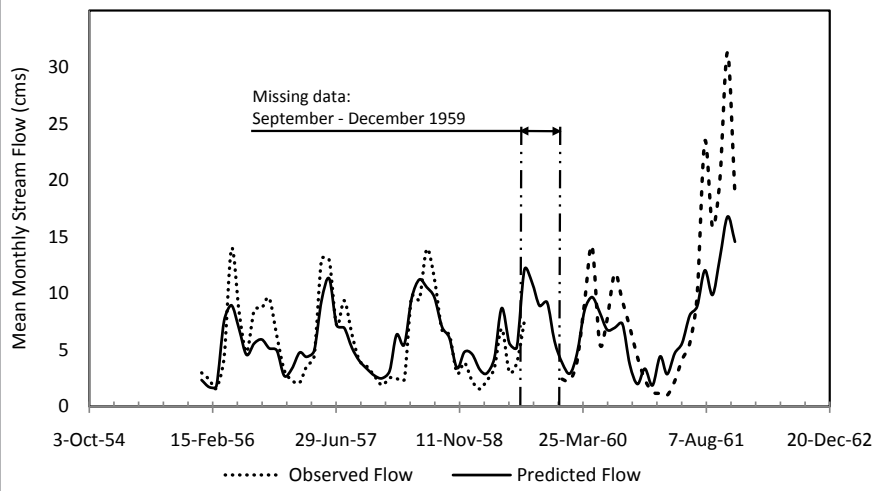

Figure 2: Observed and simulated average monthly flows for the period 1956 $-1961$.

capture peak flows was obtained by Ndomba et al. [19] who attributed the cause to errors in estimation of daily catchment rainfall. For mountainous catchments such as the Manafwa, stream flow is highly influenced by runoff and soil moisture in comparison to groundwater movement. It is therefore important that accurate rainfall data and coverage be maintained to enable efficient catchment modeling. Further investigation into the inability of the model to capture peak flows is necessary. 


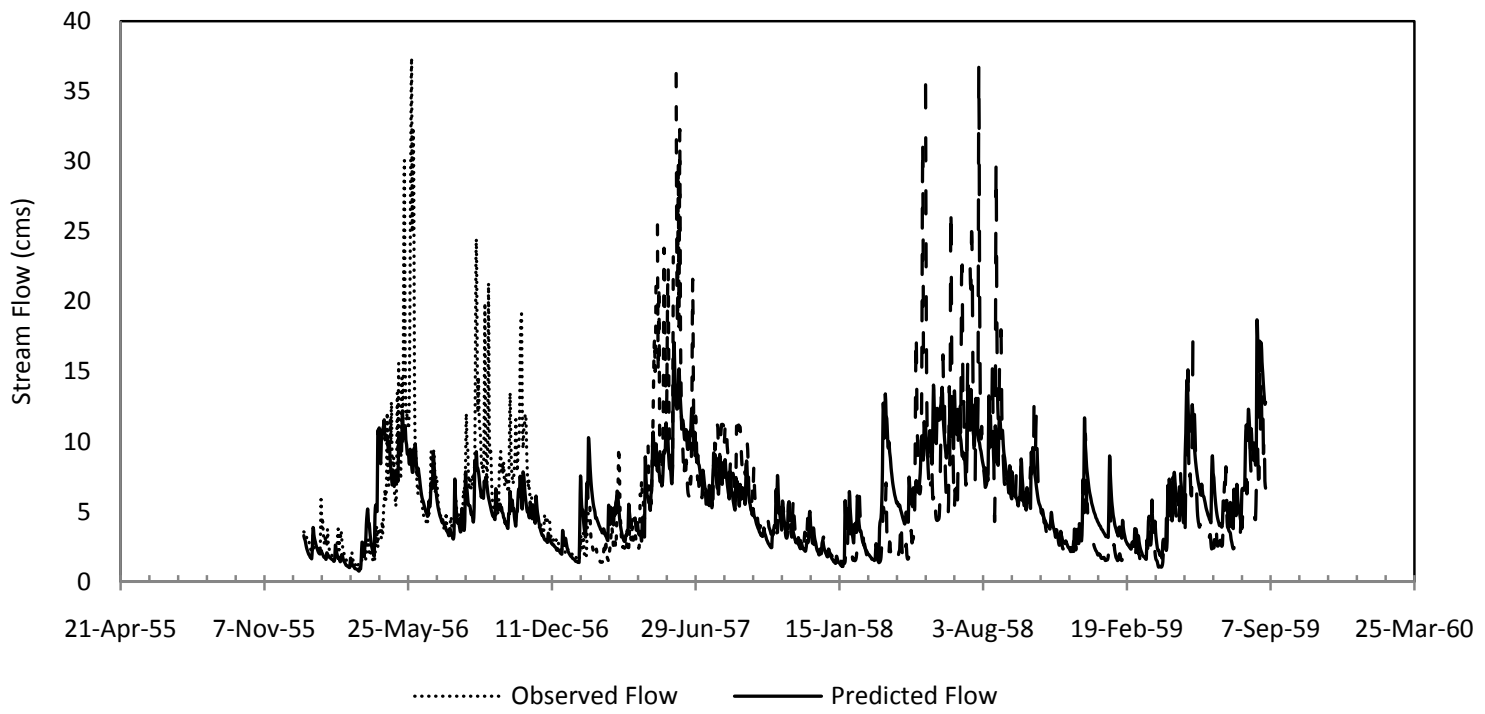

Figure 3: Observed and simulated daily flow for the calibration period (1956-1959).

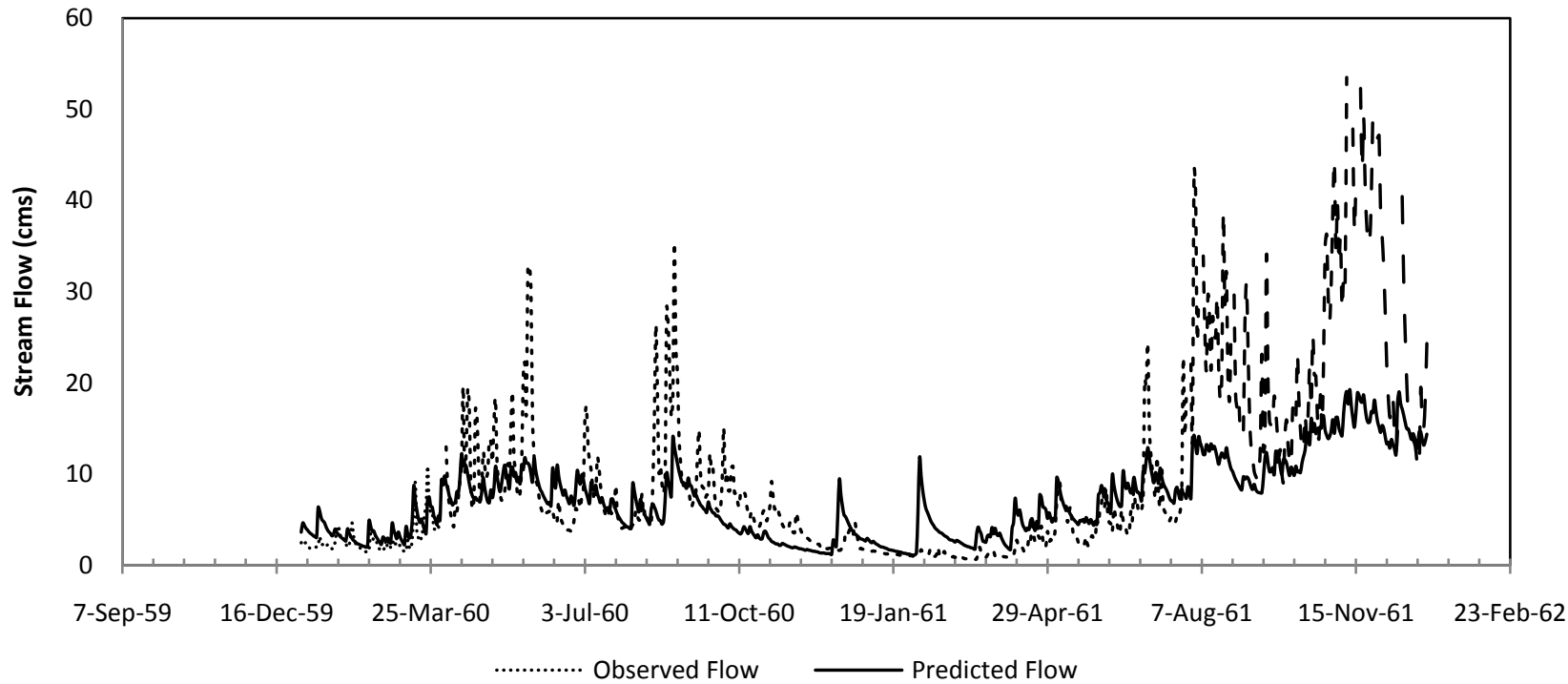

Figure 4: Observed and simulated daily flows for the validation period (1960 - 1961).

\section{Conclusions}

This study aimed at assessing the effectiveness of the SWAT model for predicting the flows of river Manafwa in Uganda. This was meant to determine whether SWAT is a suitable alternative for modelling mountainous data-scarce catchments in tropical Africa and therefore could be applicable for water resources assessments. The SWAT model was successfully applied to simulate the hydrology of the river Manafwa watershed on a monthly basis, which is confirms SWAT's capability to capture monthly flow trends regardless of catchment characteristics and location. However, the model falls short of capturing peak flows when run at a daily time step. This inability of the model to capture peak flows that occur during the wet seasons was found to be the primary limiting factor for its performance. In contrast to non-mountainous catchments where a small number of rain gauges can capture rainfall pattern, for tropical mountainous regions such as the Manafwa catchment the accuracy of rainfall data and coverage has a large influence on stream flow peaks. As such, to enable model improvement more weather stations should be installed to capture microclimates within the study area.

\section{Acknowledgments}

The authors would like to thank the Global Center for Food Systems Innovation at Michigan State University for partial funding of this project.

\section{References}

1. WMO World Meteorological Organization (2012) Technical Material for Wate Resources Assessment. Technical Report Series No 2, WMO-No 1095 WMO Geneva Switzerland.

2. Loucks DP (1992) Water resource systems models: Their role in planning Journal of Water Resources Planning and Management 118: 214-223.

3. Jeremiah E, Sisson SS, Sharma A, Marshall L (2012) Efficient hydrological 
Citation: Mutenyo I, Nejadhashemi AP, Woznicki SA, Giri S (2013) Evaluation of SWAT Performance on a Mountainous Watershed in Tropical Africa Hydrol Current Res S14: 001. doi:10.4172/2157-7587.S14-001

model parameter optimization with Sequential Monte Carlo sampling. Environmental Modelling and Software 38: 283-295.

4. Duan Q, Sorooshian S, Gupta VK (1994) Optimal use of the SCE-UA global optimization method for calibrating watershed models. Journal of Hydrology 158: $265-284$.

5. Nejadhashemi AP, Smith CM, Hragrove WL (2009) Adaptive Watershed Modelling and Economic Analysis for Agricultural Watersheds: An approach to integrate local stakeholder knowledge with the best science, Kansas State University Agricultural Experiment Station and Cooperative Extension Service MF2847: 1-8.

6. Srinivasan R, Ramanayan TS, Arnold JG, Bednarz ST (1998) Large area hydrologic modelling and assessment Part II: Model application. Journal of American Water Resources Association 34: 91-101.

7. Gassman PW, Reyes MR, Green CH, Arnold JG (2007) The Soil and Water Assessment Tool: Historical Development, Applications and Future Research Directions. Working Paper 07-WP 443 Centre for Agriculture and Rura Development, lowa State University, USA.

8. Jayakrishnan R, Srinivasan R, Santhi C, Arnold JG (2005) Advances in the Application of the SWAT model for water resources management. Hydrological Processes 19: 749-762.

9. USEPA United States Environmental Protection Agency (2000) Overview of Current Total maximum Daily Load-TMDL-Program and Regulations. Office of Water (4503F) Washington DC, USA.

10. Arnold JG, Srinivasan R, Muttiah RS, Williams JR (1998) Large Area Hydrologic Modelling and Assessment Part I: Model Development. Journal of American Water Resources Association, 34: 73-89.

11. Abaho P, Amanda B, Kigobe M, Kizza M, Rugumayo A (2009) Climate change and its impact on river flows and recharge in the Sezibwa catchment, Uganda. Second International Conference on Advanced in Engineering and Technology $572-578$.

12. Mulungu DMM, Munishi SH (2007) Simiyu River catchment parameterization using SWAT model. Journal of Science Direct. Physics and Chemistry of the Earth, 32: 1032-1039.

13. Ndomba PM, Magoma D, Mtalo FW, and Nobert J (2010) Application of SWAT in Natural Wetland catchments. A Case of Rugezi Catchment in Rwanda. Nile Basin Water Science \& Engineering Journal 3: 1-13.

14. Nyeko M (2010) Land use changes in Aswa basin-northern Uganda: Opportunities and constrains to water resources management, Ph.D. dissertation, University of Naples Federico II.

15. Melesse AM, McClain M, Wang X, Abira M, Mutayoba W (2008) Modeling the Impact of Land-Cover and Rainfall Regime Change Scenarios on the Flow of Mara River, Kenya.

16. Setegn SG, Rayner D, Melesse AM, Dargahi B, Srinivasan R (2011) Impact of climate change on the hydroclimatology of Lake Tana Basin, Ethiopia. Water Resources Research 47: 1-13.

17. Phomcha P, Wirojanagud P, Vangpaisal T, Thaveevouthti T (2011) Suitability of SWAT model for simulating of monthly streamflow in Lam Sonthi watershed. The Journal of Industrial Technology 7: 49-56.

18. Baker TJ, Miller SN (2013) Using the Soil and Water Assessment Tool (SWAT) to assess land use impact on water resources in an East African watershed. Journal of Hydrology486: 100-111.

19. Ndomba $P$, Mtalo $F$, Killingtveit $A$ (2008) SWAT model application in a data scarce tropical complex in Tanzania. Physics and Chemistry of the Earth 33: 626-632.

20. Birhanu BZ (2009) Hydrological Modelling of the Kihansi River Catchment in South Central Tanzania using SWAT Model. International Journal of Water Resources and Environmental Engineering 1: 1-10.
21. Kingston DG, Taylor RG (2010) Projected impacts of climate change on groundwater and storm flow in a humid, tropical catchment in the Uganda upper Nile basin. Journal of Hydrology and Earth Systems Sciences Discussions 7 : 1913-1944.

22. Van Griensven A, Ndomba P, Yalew S, Kalonzo F (2012) Critical review of SWAT in the upper Nile basin countries. Hydrology and Earth System Sciences Discussions 9: 3761-3788.

23. Isabirye M, Mbeera D, Ssalli H, Magunda M, Lwasa J (2004) Soil Resources Information and Linkages to agricultural production. Uganda Journal of Agricultural Sciences, National Agricultural Research Organisation NARO Uganda 9: 215-221.

24. Semalulu O, Kimaro D, Kasenge V, Isabirye M, Makhosi P (2012) Soil and nutrient losses in banana-based cropping systems of the Mount Elgon hillsides of Uganda: Economic implications. International Journal of Agricultural Sciences 2: 256-262.

25. Neitsch SL, Arnold JG, Kiniry JR, Williams JR (2011) Soil and water assessment tool theoretical documentation Version 2009. Technical report No 406, Texas Water Resources Institute.

26. Winchell M, Srinivasan R, Di Luzio M, Arnold JG (2010) ArcSWAT Interface fo SWAT 2009 User's Guide. Blackland Research and Extension Centre Texas Grassland, Soil and Water Research laboratory USDA Agricultural Research Centre Temple, Texas USA.

27. FAO (2003) Digital Soil Map of the World. Land and Water Development Division, Food and Agriculture Organization, Rome.

28. Mugagga F, Kakembo V, Buyinza M (2011) A characterization of the physical properties of soil and the implications for Landslide occurrence on the slopes of Mount Elgon, Eastern Uganda. Natural Hazards 60: 1113-1131.

29. NEMA (2010) Landslides in Bududa district, Their causes and consequences pp.16.

30. Kitutu MG, Muwanga A, Poesen J, Deckers JA (2009) Influence of soil properties on landslide occurrence in Bududa District, Eastern Uganda. African Journal of Agricultural Research 4: 611-620.

31. Braun AR, Smaling E, Muchungu EI, Shepherd KD, Corbett JD (1997) Maintenance and Improvement of Soil productivity in the Highlands of Ethiopia, Kenya, Madagascar and Uganda.

32. Webb RS, Rosenzweig CE, Levine ER (1991) A Global data set of soil particle size properties. National Aeronautical and Space Administration Scientific and Technical Program, pp. 33

33. Mubiru J, Banda EJKB (2012) Monthly average daily global solar irradiation maps for Uganda: A location in the equatorial region. Renewable Energy 41 : 412-415.

34. Arnold JD, Moriasi DN, Gassman PW, Abbaspour KC, White MJ, et al. (2012) SWAT: Model Use, Calibration and Validation. Transactions of the ASABE 55 1491-1508.

35. Moriasi DN, Arnold JG, Van Liew MW, Bingner RL, HarmelRD, et al. (2007) Model evaluation guidelines for systematic quantification of accuracy in watershed simulations. Transactions of the ASABE 50: 885-900.

36. Arnold JG, Kiniry JR, Srinivasan R, Williams JR, Haney EB, et al. (2011) So and water Assessment Tool Input/Output File Documentation Version. 2009 Technical Report No 365, Texas Water Resources Institute, Texas A\&M University System, USA.

37. Nash JE, Sutcliffe JV (1970) River flow forecasting through conceptual models Part 1: A Discussion of principles. Journal of Hydrology 10: 282-290.

38. Refsgaard JC (1997) Parameterisation, calibration and validation of distributed hydrological models. Journal of Hydrology 198: 69-97.

This article was originally published in a special issue, Application of Forecasting Models in Hydrology handled by Editor(s). Dr. Mohammad Valipour, University of Tehran, Iran, Islamic Republic Of 